\author{
Journal of Analytic Divinity \\ International Refereed Journal \\ E-ISSN: 2602-3792 \\ Haziran/June, 2020/ 4 (1): ss-pp 86/103
}

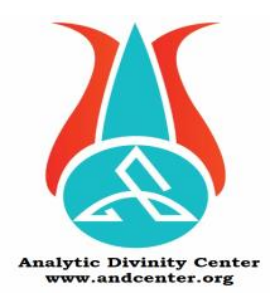

\title{
4-6 Yaş Kur'an Kursu Öğreticilerinin Okul Öncesi Dönem Müzik Eğitimine İlişkin Tutumları Üzerine Bir Araştırma
}

A Research on the Attitudes of the Teachers Working in the Qur'an Courses Designed for the Four-to-Six-Year-Old Children on the Preschool Music Education

\section{Sadettin Volkan Kopar}

Dr. Öğr. Üyesi, Ankara Yıldırım Beyazıt Üniversitesi, Türk Musikisi Devlet Konservatuvarı Assist. Prof. Ankara Yıldırım Beyazıt University, Turkish Music State Conservatory vkopar@ybu.edu.tr, Ankara-Turkey https:/ / orcid.org/0000-0002-3164-447X

\section{Serbülend Arpa}

Dr. Öğr. Üyesi, Ankara Yıldırım Beyazıt Üniversitesi, Türk Musikisi Devlet Konservatuvarı Assist. Prof. Ankara Yıldırım Beyazıt University, Turkish Music State Conservatory sarpa@ybu.edu.tr, Ankara-Turkey https:/ / orcid.org/0000-0002-6370-4414

\section{Makale Bilgisi | Article Information}

Makale Türü / Article Type: Araştırma Makalesi / Research Article

Geliş Tarihi / Date Received: Mart/ March 2020

Kabul Tarihi / Date Accepted: May1s/ May 2020

Yayın Tarihi / Date Published: 15 Haziran /15 June 2020

Yayin Sezonu / Pub Date Season: Yaz-Haziran / Summer-June

DOI: https://doi.org/10.46595/jad.729712

Cite as / Atıf: Kopar, Sadettin V.-Arpa, Serbülend. "4-6 Yaş Kur’an Kursu

Öğreticilerinin Okul Öncesi Dönem Müzik Eğitimine İlişkin Tutumları Üzerine Bir Araştırma". Journal of Analytic Divinity, 4/1 (June 2020): 86-103.

İntihal: Bu makale, iThenticate yazılımınca taranmıştır. İntihal tespit edilmemiştir. Plagiarism: This article has been scanned by iThenticate. No plagiarism detected. web: http:/ / dergipark.gov.tr/jad | e-mail to: editorjand@gmail.com

Copyright $\odot$ Published by Özcan Güngör, Ankara Yıldırım Beyazıt Üniversitesi, İslami İlimler Fakültesi / Ankara Yıldırım Beyazıt University, Faculty of Islamic Studies, Ankara-Turkey. Bütün hakları saklıdır. / All right reserved. 


\section{Öz}

Okul öncesi dönem, çocukların zekâ ve motor becerilerini geliştirdiği ve bunları uyum içinde kullanmaya başladığı hızlı bir gelişim dönemidir. Okul öncesi eğitim, çocukların gerek bireysel özelliklerini gerekse psikolojik gelişimlerini dikkate alarak onlara iyi bir rehberlik sağlamayı amaçlamaktadır. Nitekim çocukların bu dönemde edindikleri beceri, düşünce ve davranışlar gelecekteki yaşamlarını önemli ölçüde etkilemektedir. Artan bilişsel kapasitelerine rağmen, okul öncesi çocuklar dini kavramları ve uygulamaları anlamakta bazı zorluklar yaşamaktadırlar. Bu zorlukların aşılabilmesini sağlayacak bir takım pedagojik teknikler geliştirmek üzere son yıllarda pek çok araştırma yapılmıştır.

Bu çalışma, okul öncesi çocukların, motor becerilerini melodiler yoluyla öğrenme sürecine dahil ettikleri takdirde dini terimleri ve ifadeleri daha hızlı öğrenebilecekleri, müzik eşliğinde öğrendikleri şeyleri zihinlerinde daha kalıcı bir şekilde tutabilecekleri ve müzik sayesinde söz konusu kavramların onların maneviyat dünyası açısından daha anlamlı hale geleceği gibi bazı varsayımlardan hareket etmektedir.

Müzik eğitiminin okul öncesi çocukların duygusal, sosyal, düşünsel, dilsel ve psiko-motor gelişimi üzerindeki olumlu etkilerinin kısa bir özetini veren makale, yazarlar tarafından hazırlanıp uygulanan beşli Likert ölçeği anket verilerine göre belirtilen varsayımların ne derece geçerli olduğunu ortaya koymaktadır. Makale, Diyanet İşleri Başkanlığı Ankara Müftülüğüne bağlı Dört-Altı Yaş Kur'an Kurslarında görev yapan öğreticilerden elde edilen bulguların değerlendirilmesi ile sona ermektedir.

Anahtar kelimeler: Okul öncesi, Öğretmen, Din, Müzik, Eğitim.

\section{Abstract}

The preschool period is a time of rapid growth when children develop intelligence and motor skills and start to use them both in harmony. Preschool education is meant to provide the best guidance for the children taking into account their individual characteristics and psychological development because the skills, thoughts, and behaviors they acquire in this period will greatly affect their future life. Despite their increasing cognitive capacity, preschool kids have difficulty understanding religious concepts and practices. That is why many pieces of research were made into the more effective pedagogical techniques in this regard over the last few decades.

This study moves from the assumption that the children would learn religious terms and phrases more quickly through melodies by involving their motor skills into the process of learning. Accompanied by music, the learned things would remain firm and permanent in their minds and make sense in a good way for their spirituality.

Having given a brief outline of the positive effects of music education on the emotional, social, intellectual, lingual, and psycho-motor development of preschool

Journal of Analytic Divinity, https://dergipark.org.tr/tr/pub/jad Volume 4/1 
children, the article showcases whether the preliminary assumptions proved true through a five-point Likert scale survey questionnaire prepared and carried out by the authors. The article is ending with an assessment of the findings gathered from teachers working in the Qur'an Courses opened for the four-to-six-year old children by the Office of the Mufti of Ankara (Ankara Muftulugu), which is attached to the Presidency of Religious Affairs.

Key words: Pre-School, Teacher, Religious, Music, Education.

\section{Giriş}

Okul öncesi dönem, bireyin gelecek temellerinin atıldığı, temel bilgi ve beceriler kazanarak gelişiminin oldukça hızlı olduğu bir dönemdir. Gelişim ve öğrenmenin en yoğun yaşandığı bu dönem çocukların fiziksel, zihinsel, sosyal, duygusal ve dil gelişimi gösterdikleri desteklenmesi gereken bir süreçtir. Gelişen dünya ve toplumlarda önemi her geçen gün daha da artan okul öncesi eğitim, çocukta kalıcı etkiler bırakması sebebiyle göz ardı edilmesi mümkün olmayan bir dönemdir. Çocukların bireysel özellikleri ve gelişim ivmelerini dikkate alarak onları en doğru alanlara yönlendirmeyi hedefleyen okul öncesi eğitim, öğretilen ve kazandırılan davranış biçimlerinin hayat boyunca devam edeceği olgusunu merkeze alan sistemli bir süreçtir. Okul öncesi dönemde, okuma-yazma bilmemeye bağlı olarak genellikle gözlem ve dinleme yöntemiyle bilgi edinme süreci söz konusu olduğundan görsel ve işitsel algılamaya bağlı eğitime önemli bir rol düşmektedir.

Müzik, okul öncesi dönem çocukları için tabii ve etkin bir oyun aracıdır. Müzik icrası ile oyun oynayan çocuklar aynı zamanda öğrenirler. Şarkı söylerken uyuma dikkat etme, bazı salınım hareketlerini beraber yapma onlar için yeni keşifleri ve farklı tecrübeleri beraberinde getirir. Bu nedenle okul öncesi çocukların eğitimleri müzikten ayrı düşünülemez. Müziğin doğru icra edilmesi çabası onları disipline eden bir nitelik olarak da düşünülebilir. Çünkü müzik icrası için belirli bir ritmik kalıba uyulması ve ortak paydalarda buluşulması gerekir. Ayrıca yaratıcı etkinliklerinin, sağladığı geniş ve uyarıcı ortam nedeniyle okul öncesi dönem çocuklarının yaşamında önemli bir yeri vardır (aktaran Yıldız - Nacakc1, 2016, 40).

Erken çocukluk dönemi eğitiminin müzik eşliğinde yapılmasının çocukların konuşmalarına, bazı kelime ve kavramları anlamasına da etkisi vardır. Müzik, çocuğun algısının açılmasına, sorun çözme yeteneğini kazanmasına, özgüven sağlayarak keşif sürecini hızlandırmasına sebep olur. Bu sürece ebeveynlerin dâhil olması, evlerinde zenginleştirilmiş mekânlar oluşturarak bir takım etkinliklere bizzat katılması gerekir (Soysal, 2012, 194).

Okul öncesi 4 yaş döneminde çocuklar hareketli kısa şarkıları kolaylıkla ezberleyip tekrar edebilirler. Belirli bir ses tonu edinmeye başlayan bu yaştaki çocuklar, ses kaynağı, süre (ritim/tempo) ve perde (frekans) sınıflandırmasını başlangıç düzeyinde yapabilirler. 5 yaş çocuğu ritme uygun şarkı söyleyebilir. Bu şarkılarla hem eğlenir hem de kelime dağarcı̆̆ını genişletir. 6 yaş çocuğunda beğeni ön plana çıkar. Kendi seçtiği şarkıları 
Kopar, Sadettin V.-Arpa, Serbülend. 4-6 Yaş Kur’an Kursu Öğreticilerinin Okul Öncesi...

söylemeyi sever. Ritim algısı yükselir. Şarkı söylemekten zevk alır. Müzikle ilgili duygularını rahatlıkla ifade edebilir (Okumuş, 2008, 14-15).

Bireylerin müziksel yeteneklerini geliştirmek amacıyla küçük yaşlardan itibaren verilen müzik eğitiminin bilişsel gelişim ve dil gelişimi, sosyal ve duygusal gelişim, bedensel ve psiko-motor gelişim üzerindeki olumlu etkileri yapılan pek çok araştırmayla ortaya konulmuştur (Gün vd., 2016, 118).

Bireyin yetişkinlikte sahip olacağ eğitime bağlı olarak şekillenecektir (Genç, 2019, 507). İdeal dini gelişimin sağlanabilmesi için din dilinin ve dini söylemlerin okul öncesi çocukların alg1 seviyesi ile uyumlu olacak şekilde belirlenmesi gerekir. Burada doğru bilginin önemi ortaya çıkmaktadır. Farklı kanallardan edilmiş farklı bilgiler çocuğun duygu bütünlüğüne zarar verebilir. Din eğitiminin belli kriterler konularak yürütülmesi, eğitim programlarının bilimsel temellerden yoksun olmaması gerekir. Eğitimcilerin hem din eğitiminin temel prensiplerini hem de çocukluk dönemi gelişim özelliklerini çok iyi bilinmesi önem arz eder (Türk, 2014, 144).

Okul öncesi dönem din eğitiminde çocuğun hisleri de önemlidir. Beğenileri üzerinden pek çok bilgi aktarımı yapılabilir. Sözgelimi "melek" kavramı onda iyiliği, güveni ve yardımseverliği çağrıştırabilir. Somut olaylarla soyut kavramları eşleştirmeye başlayabilir. Bu nedenle okul öncesi dönem, çocuğun tabii gelişiminin, seciye ve karakterinin oluşumunun önemli bir evresidir. Duygu ve hissiyatını içselleştirdiği, kendine özgü tutum ve tavırları, inanışları kategorize ettiği sürecinin başlangıcıdır. Bu süreçte din eğitimi doğrudan değil dolaylı olarak verilmelidir (Yağcı, 2018, 56). Dolaylı din eğitimin en yaygın aracı ise müziktir.

Çocuklarda oyun, öğrenme yöntemlerinin başında gelmektedir. Çocuklar eğlenerek öğrenme eylemini gerçekleştirdikleri gibi öğrenerek de eğlenme eylemini gerçekleştirirler. Her yeni bilgi ve keşif onları heyecanlandırır ve zevk almalarını sağlar. Bu nedenle oyun oynamayı salt eğlence olarak değerlendirmek yanlış olur. Ayrıca çocukların dil ve zihinsel gelişimlerinin üst düzeye ulaşmasıyla birlikte özellikle melodiyle söylenen ve hareketlerle eşlik edilebilen dini uygulamalarla aktivite ya da kavram ve ifadeler, kolaylıkla ve eğlenceli bir şekilde öğretilebilir (Tosun - Çapcıoğlu, 2015, 710).

07.04.2012 tarih ve 28257 sayılı Resmî Gazete'de yayınlanarak yürülüğe giren "Diyanet İşleri Başkanlĭgı Kur'an Ĕ̆itim ve Öğretimine Yönelik Kurslar ile Öğrenci Yurt ve Pansiyonlar Yönetmeliği" ile 03.03.2000 tarih ve 23982 sayılı Resmî Gazete yayınlanan "Diyanet İşleri Başkanlı̆̆ı Kur'an Kurslar İle Öğrenci Yurt ve Pansiyonları Yönetmeliği" nin 8. maddesinin b bendinde yer alan "İlköğretimi bitirmiş olmak" şartı kaldırılmış, bu sebeple Diyanet İşleri Başkanlığı tarafından okul öncesi çocukların Kur'an Kurslarına kabul edilmelerinin önü açılmıştır. Diyanet İşleri Başkanlığınca hazırlanan 2019 Yılı Faaliyet Raporuna göre; 4-6 Yaş Grubu Din Eğitimi (2018-2019 eğitim-öğretim döneminde) 7.963 kursta; 3.728 kadrolu, 5.591 geçici olmak üzere toplam 9.319 öğretici görev yapmış, bu kurslarda $\mathbf{8 4 . 8 3 9}$ erkek çocuk, $\mathbf{8 5 . 6 7 4}$ kız çocuk olmak üzere toplam $\mathbf{1 7 0 . 5 1 3}$ öğrenci eğitim görmüştür (Erbaş, 2020).

Öğreticilerin bu eğitimde müziği tanımaları ve önemini bilmeleri gerekir. Ayrıca okul öncesi dönemde kullanılabilen müzik türlerini doğru yöntemlerle uygulayabilmeleri için örgün eğitim almalarına da ihtiyaç vardır. Böylece öğreticiler müzik eşliğinde yaptıkları

Journal of Analytic Divinity, https://dergipark.org.tr/tr/pub/jad Volume 4/1 
uygulamalarla bir taraftan çocuklara müziğin gizemli dünyasını keşfetmede yardımcı olup özel yeteneklerini ortaya çıkarmayı başarabilecekler (Öztürk, 2011,16) diğer taraftan da din eğitimini daha etkin ve kalıcı bir şekilde gerçekleştirebileceklerdir.

Bu çalışmada, okul öncesi dönemde müzik eğitimin çocukların duygusal ve sosyal, bilişsel, dil ve psiko-motor gelişimlerine yönelik etkilerinden bahsedilecek, daha sonra Diyanet İşleri Başkanlığı 4-6 yaş Kur'an Kurslarında görev yapan öğreticilere uygulanan ankete yönelik bulgular ve analizlere yer verilecektir.

\section{Duygusal ve Sosyal Gelişim}

Sosyal gelişim; bireylerin çevreye ve kurallara uyum göstermek, duygusal ve düşünsel iletişim kurabilme yetisi kazanmak şeklinde açıklanmaktadır. Bireylerin kendisi ile uyum içerisinde olması "psikolojik uyum", çevresi ile uyum içerisinde olması da "sosyal uyumdur" (Tanaltay, 1997, 140).

Okul öncesi dönemde müzik eğitimi çocuğa ruhsal, kültürel, sosyal ve zekâ gelişimi (anlayışı) bakımından bazı kavramların ve değerlerin kazandırılmasında oldukça etken bir yoldur (Şen, 2010, 338-339). Şen'e (2010) göre müzik eğitimi yoluyla çocuklara, iyi, doğru ve güzel kavratabilir. Çocuk kendi kültür ve geleneklerini müziği ve danslarıyla tanır, milli duyguları gelişir. Diğer çocuklarla beraber mutlu yaşama alışkanlığı kazanır. Hayatı algılama ve yorumlamada etkili olur.

Müzikle eğitim yönteminin kullanılması çocukların özgüvenlerini kazanmaları ve kendilerini daha özgün ifade edebilmeleri için ortam hazırlar. Çocukların müzik etkinliklerine gurup üyesi olarak katılımı; sesini kullanma ve kontrol etme, uyum becerisini geliştirme, ortak icra ile ilgili disiplinli olmayı öğretir. Bu etkinliklere çalgı çalarak bireysel katılımı ise; enerjisini olumlu yönlendirme, kişisel doyum sağlayabilme ve ritim-melodi duygusunu geliştirme türünden kazanım sağlar (Kabataş, 2017, 196-197).

\section{Bilişsel Gelişim}

Biliş kelimesine, insanın soyut ya da somut olanı anlamlandırma sürecindeki zihinsel faaliyeti anlamı verilebilir. Fidan'a $(1986,65)$ göre oldukça kapsamlı bir kavram olan biliş, insan zihninin dünyayı ve çevresindeki olayları anlamaya yönelik yaptığı işlerin tümüdür. Jean Piaget, Lev Semonovich Vygotsky, Jerome Bruner ve Robert Gagne gibi gelişim kuramcıları öğrenmeyi aktif bir süreç olarak görmekte ve öğretimin bireyin aktif katılımı ile gerçekleştirilmesi gerektiğini söylemektedir (Kol, 2011, 8-10).

Araştırmacılar, müzik eğitiminin bilişsel düşünme becerisini arttırdığını, bilişsel düşünme ile müzik arasında güçlü bir ilişki bulunduğunu saptamışlardır (Gün vd., 2016, 119). Müzikle yapılan eğitimde de aynı durum söz konusudur. Çocuk bir taraftan yeni kelime ve kavramları öğrenirken diğer taraftan da ritme uyma, melodi icrası gibi müziğin kurallarına riayet etmek zorunda kalacak, bu da çocuğun ayrıca bir zihin faaliyeti içerisinde bulunmasını gerektirecektir. Yeni şeyleri öğrenmekten zevk alan çocuğun bu zihin faaliyeti 
Kopar, Sadettin V.-Arpa, Serbülend. 4-6 Yaş Kur’an Kursu Öğreticilerinin Okul Öncesi...

onun zihin gelişimine katkı sağlayacak, tekdüze ve salt bilgiye dayalı eğitime ulaşılması mümkün olmayan farklı bakış açılarını kazanmasına sebep olabilecektir.

$\mathrm{Bu}$ nedenle müziği zihnin gelişimine katkı sağlayan önemli bir etken olarak değerlendirebiliriz. Yeni kelime ve kavramlar müzikle yapılan eğitimde daha hızlı öğretilebilir. Bu kavramların soyut olması öğrenmeyi etkilemez. Müzik çalışmalarının yardımıyla, insan bedeni ve uzuvları, çevre, diğer insanlar, doğa ve doğa olayları, sosyal yaşayış kuralları, kültürel değerler ve değer yargılarını öğretmek ve kavratmak mümkün olabileceği gibi renk, sayı, biçim, zamana ve mekâna dayalı kavramların kavratılmasında da yol alınır (Başer, 2004, 8).

Müzikal öğrenmede Emile Jaques Dalcroze (1865-1950) ritim, doğaçlama ve bedensel yaklaşımin (kinestetik); Carl Orff (1895-1982) ritim, hareket ve taklit etmenin; Zoltan Kodaly (1882-1967) halk ezgilerinin, şarkı söylemenin; Shinichi Suzuki (1898-1998) taklit etmenin önemi üzerinde durur (Erdal, 2012, 56).

\section{Dil Gelişimi}

Okul öncesi dönemde öğrenilen tekerlemelerin de belirli ezgisi ve ritim yapısı vardır. Her ne kadar içinde barındırdığı ezgi geniş aralıklar içermese de bu tekerleme sayışmaların ritmik yapısı üzerinde kullanılan kelimelerin ve kurulan cümlelerin tonalite uyumu çocuğa müzik icrası hissi verir. Bu his öğrenmeyi kolaylaştırdığı gibi ritmik yapısı gereği çocuğun telaffuz becerisini artırır, dil gelişimine katkı sağlar.

$\mathrm{Bu}$ anlamda okul öncesi çocukların yabancı olduğu, telaffuzunda zorlandığı kavramların doğru bilgilerle işlenmesi, onların algı seviyesinde metinleştirilip yaşlarına uygun tarz ve kalıpta bestelenerek öğretilmesi gerekir. Müziğin, dil gelişimini hedefleyerek, bir öğretim aracı olarak kullanılmasında öğretmenin öğrenciye diksiyon yönünden doğru model olması da gerekir (Kabataş, 2017, 196).

Dil gelişiminin içine dini kavram ve ifadelerin öğrenilmesini de eklemek gerekir. İyi bir ezberleme gücüne sahip olan çocuklar vücutlarını kullanarak melodi eşliğinde bu kavram ve kalıp ifadeleri daha çabuk öğrenebilirler. Bu metotla öğrenilen yeni kelime ve dini kavramların çocukların anlam dünyasında daha net karşılık bulacağı ve kalıcı olacağı söylenebilir.

\section{Psiko-motor ve Bedensel Gelişim}

Okul öncesi müzikle eğitimde çocuğun bedensel aktiviteler sergilemesi kaçınılmazdır. Bu aktiviteler icra edilen müziğin ritmik yapısına ve ezgisine göre şekil alır. Çocuğu bedensel aktiviteye yönlendirir. Müzik eşliğinde oynanan oyunlarda da durum böyledir. Aktiviteler kas gelişimini sağlar. Çocuğun müziğe, vücut hareketleriyle tepki vermesi, müziğe uygun dans figürleri oluşturmaya çalışması, müziğe sesiyle eşlik ederek, sesini tanıması bilişsel ve psiko-motor gelişimine katkı sağlar (Ömeroğlu vd., 2003, 17-18).

Çocukların, bebeklik döneminde başlayan müziksel gelişim sürecinde, ses perdelerini alçaltıp yükselterek sesler çıkarmaları, duydukları sese doğru dönmeleri, duydukları ezgi, ninni ve şarkılarda ağlamalarını kesip dikkat göstermeleri, müzik aletlerini sallayarak, eliyle vurarak veya tellerine dokunarak ulanmaları, sesleri çıkarırken,

Journal of Analytic Divinity, https://dergipark.org.tr/tr/pub/jad Volume 4/1 
giderek belli bir ses tonu elde etme arayışında olmaları, bedenini kullanarak oluşturduğu seslerle ezgilere eşlik etmeleri, eşlik ederken el çırpma, elini dize vurma, parmak kullanma, ıslık çalma, ayağını yere vurma devinimleri sergilemeleri zihinsel, bedensel ve psikomotor gelişimleri açısından sesin ve müziğin önemini göstermektedir (Yıldız, 2002).

\section{Araştırmanın Amacı}

Bu çalışmanın amacı, 4-6 yaş Kur'an Kursu öğreticilerinin okul öncesi dönem müzik eğitimine ilişkin görüşlerini tespit etmek ve yorumlamaktır.

\section{Araştırmanın Modeli}

4-6 yaş Kur'an Kursu öğreticilerinin okul öncesi dönem müzik eğitimine ilişkin görüşleri hakkında veri toplamak amacıyla betimsel araştırma modelinden yararlanılmıştır.

\section{Evren ve Örneklem}

Araştırmanın evrenini, Diyanet İşleri Başkanlığına bağlı Müftülüklerde görev yapan 4-6 yaş grubu Kur'an Kursu öğreticileri, örneklemini ise Ankara Müftülüğüne bağlı ilçe müftülüklerinde görev yapan 252 Kur'an Kursu öğreticisi oluşturmaktadır.

\section{Verilerin Toplanması}

Veri toplama sürecinde, okul öncesi dönem müzik eğitimi ile ilgili görüşlerini tespit etmek amaciyla Kur'an Kursu öğreticilerine yönelik beşli Likert ölçeğinde bir anket hazırlanmıştır. Anket öğreticilere yüz yüze uygulanmış, ankete yönelik öğreticiler tarafından sorulan sorular anında yanıtlanmıştır.

4 maddesi kişisel bilgiler, 12 maddesi okul öncesi müzik eğitimine ilişkin değerlendirme sorularından oluşan anket, üniversitelerde müzik eğitimcisi olan 3 uzmanın görüşü alınarak hazırlanmış, 252 öğreticiye uygulanmıştır.

\section{Verilerin Analizi}

$\mathrm{Bu}$ araştırmada anketlerden elde edilen verilerin frekans (f) ve yüzde (\%) dağılımları çıkartılmış daha sonra maddelerin aritmetik ortalamaları (X) hesaplanarak, yorumlanmiştır.

Olumlu ve olumsuz maddelerin yorumlanmasinda, aritmetik ortalama ve Tablo 1'deki puan aralıkları esas alınmıştır. 
Kopar, Sadettin V.-Arpa, Serbülend. 4-6 Yaş Kur’an Kursu Öğreticilerinin Okul Öncesi...

Tablo 1. Cevap Seçenekleri ve Puanlar

\begin{tabular}{|ll|}
\hline Puanlar & Cevap Seçenekleri \\
\hline $1.00-1.79$ & Hiç Katılmiyorum \\
\hline $1.80-2.59$ & Az Katıllyorum \\
\hline $2.60-3.39$ & Orta Derecede Katıllyorum \\
\hline $3.40-4.19$ & Büyük Ölçüde Katıllyorum \\
\hline $4.20-5.00$ & Tamamen Katıliyorum \\
\hline
\end{tabular}

\section{Bulgular ve Yorumlar}

Bu bölümde kişisel bilgiler ile anket maddelerine verilen cevapların frekans, yüzde ve aritmetik ortalamaları tablolarda belirtilmiş ve yorumlanmıştır.

\section{Demografik Bilgiler}

Tablo 2. Öğreticilerin Eğitim Durumu

\begin{tabular}{|l|l|l|}
\cline { 2 - 3 } \multicolumn{1}{c|}{} & f & $\%$ \\
\hline Lise & 22 & 8,7 \\
\hline Ön Lisans & 111 & 44,1 \\
\hline Lisans & 114 & 45,2 \\
\hline Yüksek Lisans & 5 & 2 \\
\hline Toplam & 252 & 100 \\
\hline
\end{tabular}

Tablo 2'de görüldüğü gibi, araştırmaya katılan 4-6 yaş Kur'an Kurslarındaki öğreticilerin \%8,7'si lise, \%44,1'i ön lisans, \%45,2'si lisans, \%2'si yüksek lisans mezunu olduklarını belirtmişlerdir. Bu verilere göre, 4-6 yaş Kur'an Kurslarındaki öğreticilerin çoğunlukla ön lisans ve lisans eğitim düzeyinde olduğunu söyleyebiliriz.

Tablo 3. Öğreticilerin Çalışma Deneyimi

\begin{tabular}{|c|c|c|}
\hline & $\mathrm{f}$ & $\%$ \\
\hline $0-1 Y_{11}$ & 100 & 39,7 \\
\hline $1-2 Y_{11}$ & 51 & 20,2 \\
\hline 2-3 Yil & 38 & 15,1 \\
\hline 3-4 Yil & 19 & 7,5 \\
\hline 4-5 Yil & 11 & 4,4 \\
\hline 5 Yildan Fazla & 33 & 13,1 \\
\hline Toplam & 252 & 100 \\
\hline
\end{tabular}


Tablo 3'de görüldüğü üzere, 4-6 yaş Kur'an Kurslarındaki öğreticilerin \%39,7'si 0-1 y1l, \%20,2' si 1-2 yıl, \%15,1'i 2-3 y1l, \%7,5' i 3-4 yıl, \%4,4'ü 4-5 yıl, \%13,1'i 5 yıldan fazla süredir 4-6 yaş döneminde öğreticilik yaptığını belirtmişlerdir.

Öğreticilerin çoğunlukla 0-2 yıl aralığında 4-6 yaş grubu öğrencilerle çalışma deneyimine sahip oldukları görülmektedir.

Tablo 4. Öğreticilerin Müzikle Ŭ̆raşma Düzeyi

\begin{tabular}{|l|l|l|}
\cline { 2 - 3 } \multicolumn{1}{c|}{} & f & $\%$ \\
\hline Evet & 61 & 24,2 \\
\hline Hayir & 191 & 75,8 \\
\hline Toplam & 252 & 100 \\
\hline
\end{tabular}

Tablo 4'de görüldüğü üzere 4-6 yaş Kur'an Kurslarındaki öğreticilerinin \%24,2'si daha önce müzikle uğraştığını, \%75,8'i ise müzikle uğraşmadığını belirtmiştir. 4-6 yaş Kur'an Kurslarındaki öğreticilerinin büyük çoğunluğunun daha önce müzikle uğraşmadığını söylemek mümkündür.

Tablo 5. Öğreticilerin Çalgı Çalma Düzeyi

\begin{tabular}{|l|l|l|}
\cline { 2 - 3 } \multicolumn{1}{c|}{} & f & $\%$ \\
\hline Evet & 41 & 16,3 \\
\hline Hayır & 211 & 83,7 \\
\hline Toplam & 252 & 100 \\
\hline
\end{tabular}

Tablo 5'de görüldüğü üzere 4-6 yaş Kur'an Kurslarındaki öğreticilerinin \% 16,3'ü çalg1 çaldığını, \%83,7'si çalgı çalmadıklarını belirtmişlerdir. Öğreticilerin büyük çoğunluğunun çalgı çalmadığını söyleyebiliriz.

Tablo 6. Çalınan Çalgı Sayısı

\begin{tabular}{|c|c|c|}
\cline { 2 - 3 } \multicolumn{1}{c|}{} & f & $\%$ \\
\hline Bir Çalg1 & 41 & 75,9 \\
\hline İki Çalg1 & 11 & 20,4 \\
\hline Üç Çalg1 & 2 & 3,7 \\
\hline Toplam & 54 & 100 \\
\hline
\end{tabular}

Tablo 6' da görüldü̈̆ü üzere, 4-6 yaş Kur'an Kurslarındaki çalg1 çalan öğreticilerin $\% 75,9^{\prime}$ u bir çalg1 çaldığını, \%20,4'ü iki çalg1 çaldığını, \%3,7'si üç çalg1 çaldığı cevabını vermişlerdir. 
Kopar, Sadettin V.-Arpa, Serbülend. 4-6 Yaş Kur’an Kursu Öğreticilerinin Okul Öncesi...

Tablo 7. Çalgı Türü

\begin{tabular}{|l|l|l|}
\hline Çalgi & f & $\%$ \\
\hline Bağlama & 1 & 1,9 \\
\hline Bendir & 12 & 22,2 \\
\hline Blok Flüt & 6 & 11,1 \\
\hline Def & 9 & 16,7 \\
\hline Erbane & 1 & 1,9 \\
\hline Gitar & 4 & 7,4 \\
\hline Keman & 3 & 5,6 \\
\hline Melodika & 1 & 1,9 \\
\hline Ney & 13 & 24,1 \\
\hline Org & 1 & 1,9 \\
\hline Piyano & 2 & 3,7 \\
\hline Ud & 1 & 1,9 \\
\hline Toplam & 54 & 100 \\
\hline
\end{tabular}

Tablo 7'de görüldüğü üzere 4-6 yaş Kur'an Kurslarındaki çalgı çalan öğreticilerin $\% 1,9^{\prime}$ u bağlama, $\% 22,2$ 'si bendir, $\% 11,1^{\prime}$ i blok flüt, $\% 16,7^{\prime}$ si def, $\% 1,9^{\prime}$ u erbane, $\% 7,4^{\prime}$ ü gitar, $\% 5,6$ 's keman, \%1,9'u melodika, \%24,1'i ney, \%1,9'u org, \%3,7'si piyano, \%1,9'u ud çaldığ1 cevabını vermişlerdir.

Bu veriler ışığında, 4-6 yaş Kur'an Kurslarındaki çalgı çalan öğreticilerin çoğunlukla Türk Din Mûsikîsinde de kullanılan çalgıları (bendir, ney, def, erbane) çaldıklarını söyleyebiliriz.

\section{Ölçek Maddelerine İlişkin Sonuçlar}

Tablo 8. Okul Öncesi Dönemde Müzik Eğitimini Gerekli Görme Düzeyi

\begin{tabular}{|c|c|c|c|}
\hline $\begin{array}{c}\text { Okul öncesi dönemde müzik } \\
\text { eğitimine gerek vardır. }\end{array}$ & $\mathbf{f}$ & $\mathbf{\%}$ & $\mathbf{X}$ \\
\hline Hiç Katılmıyorum & 1 & 0,4 \\
\hline Az Katılıyorum & 8 & 3,2 \\
\hline Orta Derecede Katılıyorum & 29 & 11,5 \\
\hline Büyük Ölçüde Katılıyorum & 45 & 17,9 \\
\hline Tamamen Katılıyorum & 169 & 67,1 \\
\hline Toplam & 252 & 100 \\
\hline
\end{tabular}

Tablo 8 incelendiğinde "Okul öncesi dönemde müzik eğitimine gerek vardır" maddesine 4-6 yaş Kur' an Kurslarındaki öğreticilerin, \%0,4'ü hiç katılmadıklarını, \%3,2'si az katıldığını, \%11,5'i orta derecede katıldığını, \%17,9'u büyük ölçüde katıldığını, \%67,1'i tamamen katıldığını belirtmişlerdir. Bu maddeye ilişkin ortalama 4,18 (büyük ölçüde katıllyorum) düzeyinde gerçekleşmiştir. 
Bu verilere göre, 4-6 yaş Kur'an Kurslarındaki öğreticilerin okul öncesi dönemde müzik eğitimine gerekli olduğunu düşündüklerini söyleyebiliriz.

Tablo 9. Okul Öncesi Dönemde Müzik Eğitimi Çocukların Psiko-motor ve Bedensel Gelişimine Katkı Sağlama Düzeyi

\begin{tabular}{|c|c|c|c|}
\hline $\begin{array}{c}\text { Okul öncesi dönemde müzik } \\
\text { eğitimi çocuğun psiko-motor ve } \\
\text { bedensel gelişimine katkı sağlar. }\end{array}$ & f & $\%$ & X \\
\hline Hiç Katılmıyorum & 0 & 0 \\
\hline Az Katılıyorum & 8 & 3,2 \\
\hline Orta Derecede Katıllyorum & 20 & 7,9 \\
\hline Büyük Ölçüde Katıllyorum & 55 & 21,8 & 4,22 \\
\hline Tamamen Katıllyorum & 169 & 67,1 \\
\hline Toplam & 252 & 100 & \\
\hline
\end{tabular}

Tablo 9 incelendiğinde, "Okul öncesi dönemde müzik eğitimi çocuğun psiko-motor ve bedensel gelişimine katkı sağlar" maddesine 4-6 yaş Kur'an Kurslarındaki öğreticilerin, \%3,2'si az katıldığını, \%7,9'u orta derecede katıldığını, \%21,8'i büyük ölçüde katıldığını, \%67,1'i tamamen katıldığını belirtmişlerdir. Bu maddeye ilişkin ortalama 4,22 (tamamen katıliyorum) düzeyinde gerçekleşmiştir.

$\mathrm{Bu}$ verilere göre, 4-6 yaş Kur'an Kurslarındaki öğreticilerin okul öncesi dönemde müzik eğitiminin çocuğun psiko-motor ve bedensel gelişimine katkı sağlandığını düşündüklerini söyleyebiliriz.

Tablo 10. Okul Öncesi Dönemde Dini Ĕ̆itimin Müzik İle Verilmesinin Faydah Olma Düzeyi

\begin{tabular}{|c|c|c|c|}
\hline $\begin{array}{c}\text { Okul öncesi dönemde dini } \\
\text { eğitiminin } \\
\text { faydalı̈ır. ile verilmesi }\end{array}$ & f & \% & X \\
\hline Hiç Katılmıyorum & 8 & 3,2 \\
\hline Az Katılıyorum & 13 & 5,2 \\
\hline Orta Derecede Katıllyorum & 34 & 13,5 \\
\hline Büyük Ölçüde Katıllyorum & 80 & 31,7 \\
\hline Tamamen Katılıyorum & 117 & 46,4 \\
\hline Toplam & 252 & 100 \\
\hline
\end{tabular}

Tablo 10 incelendiğinde "Okul öncesi dönemde dini eğitimin müzik ile verilmesi faydalıdır" maddesine 4-6 yaş Kur' an Kurslarındaki öğreticilerin \%3,2' si hiç katılmadığını, \%5,2'si az katıldığını, \%13,5'i orta derecede katıldığını, \%31,7'si büyük ölçüde katıldığını, \%46,4'ü tamamen katıldığını belirtmişlerdir. Bu maddeye ilişkin ortalama 3,90 (büyük ölçüde katılıyorum) düzeyinde gerçekleşmiştir. 
Kopar, Sadettin V.-Arpa, Serbülend. 4-6 Yaş Kur’an Kursu Öğreticilerinin Okul Öncesi...

Tablodan çıkan sonuca göre, 4-6 yaş Kur'an Kurslarındaki öğreticilerin okul öncesi dönemde dini eğitimin müzik ile verilmesinin faydalı olduğunu düşündüklerini söylemek mümkündür.

Tablo 11. Okul Öncesi Dönemde Müzikle Dini Eğitim Verilmesi İle İlgili Kaynak Yeterliliği Düzeyi

\begin{tabular}{|c|c|c|c|}
\hline $\begin{array}{l}\text { Okul öncesi dönemde } \\
\text { müzikle dini eğitim verilmesi ile } \\
\text { ilgili yeterli kaynak mevcut değildir. }\end{array}$ & $\mathbf{f}$ & $\%$ & $x$ \\
\hline Hiç Katılmıyorum & 12 & 4,8 & \multirow{6}{*}{3,82} \\
\hline Az Katıliyorum & 12 & 4,8 & \\
\hline Orta Derecede Katılıyorum & 52 & 20,6 & \\
\hline Büyük Ölçüde Katılıyorum & 56 & 22,2 & \\
\hline Tamamen Katıliyorum & 120 & 47,6 & \\
\hline Toplam & 252 & 100 & \\
\hline
\end{tabular}

Tablo 11 incelendiğinde "Okul öncesi dönemde müzikle dini eğitim verilmesi ile ilgili yeterli kaynak mevcut değildir" maddesine 4-6 yaş Kur'an Kurslarındaki öğreticilerin $\% 4,8^{\prime}$ i hiç katılmadığını, \%4,8'ii az katıldığını, \%20,6'sı orta derecede katıldı̆̆ını, \%22,2'si büyük ölçüde katıldığını, \%47,6'sı tamamen katıldığını belirtmişlerdir. Bu maddeye ilişkin ortalama 3,82 (büyük ölçüde katılıyorum) düzeyinde gerçekleşmiştir.

Tablodan çıkan sonuca göre, 4-6 yaş Kur'an Kurslarındaki öğreticilerin okul öncesi dönemde müzikle dini eğitim verilmesi ile ilgili yeterli kaynağın olmadığını düşündükleri söylenebilir.

Tablo 12. Okul Öncesi Dönemde Müzik Eğitiminin Çocuğun Bilişsel Gelişimine Katkı Sağlama Düzeyi

\begin{tabular}{|c|c|c|c|}
\hline $\begin{array}{l}\text { Okul öncesi dönemde müzik eğitimi çocuğun } \\
\text { bilişsel gelişimine katkı sağlar. }\end{array}$ & $\mathbf{f}$ & $\%$ & $x$ \\
\hline Hiç Katılmıyorum & 4 & 1,6 & \multirow{6}{*}{4,10} \\
\hline Az Katıliyorum & 5 & 2 & \\
\hline Orta Derecede Katılıyorum & 26 & 10,3 & \\
\hline Büyük Ölçüde Katılıyorum & 73 & 29 & \\
\hline Tamamen Katıliyorum & 144 & 57,1 & \\
\hline Toplam & 252 & 100 & \\
\hline
\end{tabular}

Tablo 12 incelendiğinde, "Okul öncesi dönemde müzik eğitimi çocuğun bilişsel gelişimine katkı sağlar" maddesine 4-6 yaş Kur'an Kurslarındaki öğreticilerin \%1,6'sı hiç katılmadığını, \%2'si az katıldığını, \%10,3'ü orta derecede katıldığını, \%29'u büyük ölçüde katıldığını, \%57,1'i tamamen katıldığını belirtmişlerdir. Bu maddeye ilişkin ortalama 4,10 (büyük ölçüde katılıyorum) düzeyinde gerçekleşmiştir.

Tablodan çıkan sonuca göre, 4-6 yaş Kur'an Kurslarındaki öğreticilerin okul öncesi dönemde müzik eğitimi çocuğun bilişsel gelişimine katkı sağladığını düşündüklerini söylemek mümkündür. 
Tablo 13. Okul Öncesi Dönemde Müzik Eğitimi Çocuğun Dil Gelişimine Katkı Sağlama Düzeyi

\begin{tabular}{|c|c|c|c|}
\hline $\begin{array}{l}\text { Okul öncesi dönemde müzik eğitimi } \\
\text { çocuğun dil gelişimine katkı sağlar. }\end{array}$ & f & \% & X \\
\hline Hiç Katılmıyorum & 1 & 0,4 \\
\hline Az Katılıyorum & 7 & 2,8 \\
\hline Orta Derecede Katılıyorum & 14 & 5,6 \\
\hline Büyük Ölçüde Katıllyorum & 64 & 25,4 \\
\hline Tamamen Katılıyorum & 166 & 65,9 \\
\hline Toplam & 252 & 100 \\
\hline
\end{tabular}

Tablo 13 incelendiğinde, “Okul öncesi dönemde müzik eğitimi çocuğun dil gelişimine katkı sağlar" maddesine 4-6 yaş Kur'an Kurslarındaki öğreticilerin \%0,4'ü hiç katılmadığını, \%2,8'i az katıldığını, \%5,6'sı orta derecede katıldığını, \%25,4'ü büyük ölçüde katıldığını, \%65,9'u tamamen katıldığını belirtmişlerdir. Bu maddeye ilişkin ortalama 4,22 (tamamen katılıyorum) düzeyinde gerçekleşmiştir.

Tablodan çıkan sonuca göre, 4-6 yaş Kur'an Kurslarındaki öğreticilerin okul öncesi dönemde müzik eğitimi çocuğun dil gelişimine katkı sağladığını düşündüklerini söylemek mümkündür.

Tablo 14. Okul Öncesi Dönemde Müzik Eğitimi Çocuğun Duygusal ve Sosyal Gelişimine Katkı Să̆lama Düzeyi

\begin{tabular}{|c|c|c|c|}
\hline $\begin{array}{l}\text { Okul öncesi dönemde müzik eğitimi } \\
\text { çocuğun duygusal ve sosyal gelişimine } \\
\text { katkı sağlar. }\end{array}$ & f & $\%$ & $\mathbf{X}$ \\
\hline Hiç Katılmıyorum & 1 & 0,4 \\
\hline Az Katılıyorum & 9 & 3,6 \\
\hline Orta Derecede Katılıyorum & 21 & 8,3 \\
\hline Büyük Ölçüde Katıllyorum & 66 & 26,2 \\
\hline Tamamen Katıllyorum & 155 & 61,5 \\
\hline Toplam & 252 & 100 \\
\hline
\end{tabular}

Tablo 14 incelendiğinde, "Okul öncesi dönemde müzik eğitimi çocuğun duygusal ve sosyal gelişimine katkı sağlar" maddesine 4-6 yaş Kur'an Kurslarındaki öğreticilerin \%0,4'ü hiç katılmadığını, \%3,6'sı az katıldığını, \%8,3'ü orta derecede katıldığını, \%26,2'si büyük ölçüde katıldığını, \%61,5'i tamamen katıldığını belirtmişlerdir. Bu maddeye ilişkin ortalama 4,15 (büyük ölçüde katılıyorum) düzeyinde gerçekleşmiştir.

Tablodan çıkan sonuca göre, 4-6 yaş Kur'an Kurslarındaki öğreticilerin okul öncesi dönemde müzik eğitimi çocuğun duygusal ve sosyal gelişimine katkı sağladı̆̆ını düşündüklerini söyleyebiliriz. 
Kopar, Sadettin V.-Arpa, Serbülend. 4-6 Yaş Kur’an Kursu Öğreticilerinin Okul Öncesi...

Tablo 15. Okul Öncesi Dönemde Müzik Eğitimi Konusunda Yeterli Bilgiye Sahip Olma Düzeyi

\begin{tabular}{|c|c|c|c|}
\hline $\begin{array}{l}\text { Okul öncesi dönemde müzik eğitimi } \\
\text { konusunda yeterli bilgiye sahibim. }\end{array}$ & f & $\%$ & $x$ \\
\hline Hiç Katılmıyorum & 54 & 21,4 & \multirow{6}{*}{2,48} \\
\hline Az Katiliyorum & 82 & 32,5 & \\
\hline Orta Derecede Katıliyorum & 91 & 36,1 & \\
\hline Büyük Ölçüde Katılıyorum & 22 & 8,7 & \\
\hline Tamamen Katılıyorum & 3 & 1,2 & \\
\hline Toplam & 252 & 100 & \\
\hline
\end{tabular}

Tablo 15 incelendiğinde, "Okul öncesi dönemde müzik eğitimi konusunda yeterli bilgiye sahibim." maddesine 4-6 yaş Kur'an Kurslarındaki öğreticilerin \%21,4'ü hiç katılmadığını, \%32,5'i az katıldığını, \%36,1'i orta derecede katıldığını, \% 8,7'si büyük ölçüde katıldığını, \%1,2'si tamamen katıldığını belirtmişlerdir. Bu maddeye ilişkin ortalama 2,48 (az katıllyorum) düzeyinde gerçekleşmiştir.

Tablodan çıkan sonuca göre, 4-6 yaş Kur'an Kurslarındaki öğreticilerin okul öncesi dönemde müzik eğitimi ile ilgili yeterli bilgiye sahip olmadıklarını belirtmişlerdir.

Tablo 16. Okul Öncesi Dönemde Müzik Eğitimi İle İlgili Ĕğitim Alma İsteme Düzeyi

\begin{tabular}{|c|c|c|c|}
\hline $\begin{array}{l}\text { Okul öncesi dönem müzik eğitimi ile } \\
\text { ilgili eğitim almak isterim. }\end{array}$ & f & $\mathbf{\%}$ & $\mathbf{X}$ \\
\hline Hiç Katılmiyorum & 8 & 3,2 \\
\hline Az Katılıyorum & 9 & 3,6 \\
\hline Orta Derecede Katılıyorum & 23 & 9,1 \\
\hline Büyük Ölçüde Katılıyorum & 49 & 19,4 \\
\hline Tamamen Katılıyorum & 163 & 64,7 \\
\hline Toplam & 252 & 100 \\
\hline
\end{tabular}

Tablo 16 incelendiğinde, "Okul öncesi dönemde müzik eğitimi ile ilgili eğitim almak isterim" maddesine 4-6 yaş Kur'an Kurslarındaki öğreticilerin \%3,2'si hiç katılmadığını, \%3,6'sı az katıldığını, \%9,1'i orta derecede katıldığını, \%19,4'ü büyük ölçüde katıldığını, \%64,7'si tamamen katıldığını belirtmişlerdir. Bu maddeye ilişkin ortalama 4,11 (büyük ölçüde katılıyorum) düzeyinde gerçekleşmiştir.

Tablodan çıkan sonuca göre, 4-6 yaş Kur'an Kurslarındaki öğreticilerin büyük ölçüde okul öncesi dönemde müzik eğitimi ile ilgili eğitim almak istediklerini söyleyebiliriz. 
Tablo 17. Okul Öncesi Dönemde Dini Eğitim Verirken Müzikten İstifade Etme Düzeyi

\begin{tabular}{|c|c|c|c|}
\hline $\begin{array}{c}\text { Okul öncesi dönemde dini eğitim } \\
\text { verirken müzikten istifade ederim. }\end{array}$ & $\mathbf{f}$ & $\mathbf{\%}$ & $\mathbf{X}$ \\
\hline Hiç Katılmıyorum & 13 & 5,2 \\
\hline Az Katılıyorum & 27 & 10,7 \\
\hline Orta Derecede Katılıyorum & 48 & 19 \\
\hline Büyük Ölçüde Katılıyorum & 68 & 27 \\
\hline Tamamen Katılıyorum & 96 & 38,1 \\
\hline Toplam & 252 & 100 \\
\hline
\end{tabular}

Tablo 17 incelendiğinde, “Okul öncesi dönemde dini eğitim verirken müzikten istifade ederim" maddesine 4-6 yaş Kur'an Kurslarındaki öğreticilerin \%5,2'si hiç katılmadığını, \%10,7'si az katıldığını, \%19'u orta derecede katıldığını, \%27'si büyük ölçüde katıldığını, \%38,1'si tamamen katıldığını belirtmişlerdir. Bu maddeye ilişkin ortalama 3,65 (büyük ölçüde katılıyorum) düzeyinde gerçekleşmiştir.

Tablodan çıkan sonuca göre, 4-6 yaş Kur'an Kurslarındaki öğreticilerin okul öncesi dönemde dini eğitim verirken müzikten istifade ettiği söylenebilir.

Tablo 18. Okul Öncesi Dönemde Müzik Eğitimi İle İlgili Kaynaklar Yeterli Bulma Düzeyi

\begin{tabular}{|c|c|c|c|}
\hline $\begin{array}{l}\text { Okul öncesi dönemde müzik eğitimi ile } \\
\text { ilgili yeterli kaynak mevcut değildir. }\end{array}$ & f & \% & X \\
\hline Hiç Katılmıyorum & 11 & 4,4 \\
\hline Az Katıllyorum & 34 & 13,5 \\
\hline Orta Derecede Katılıyorum & 57 & 22,6 \\
\hline Büyük Ölçüde Katılıyorum & 49 & 19,4 \\
\hline Tamamen Katılıyorum & 101 & 40,1 \\
\hline Toplam & 252 & 100 \\
\hline
\end{tabular}

Tablo 18 incelendiğinde, “Okul öncesi dönemde müzik eğitimi ile ilgili yeterli kaynak mevcut değildir" maddesine 4-6 yaş Kur'an Kurslarındaki öğreticilerin \%4,4'ü hiç katılmadığını, \%13,5'i az katıldığını, \%22,6'sı orta derecede katıldığını, \%19,4'ü büyük ölçüde katıldığını, \%40,1'i tamamen katıldığını belirtmişlerdir. Bu maddeye ilişkin ortalama 3,61 (büyük ölçüde katılıyorum) düzeyinde gerçekleşmiştir.

Tablodan çıkan sonuca göre, 4-6 yaş Kur'an Kurslarındaki öğreticilerin okul öncesi dönemde müzik eğitimi ile ilgili yeterli kaynağın mevcut olmadığını düşündükleri söylenebilir.

\section{Sonuçlar}

Çalışma ile ilgili aşağıdaki sonuçlara ulaşılmıştır. 
Kopar, Sadettin V.-Arpa, Serbülend. 4-6 Yaş Kur'an Kursu Öğreticilerinin Okul Öncesi...

$\checkmark$ Araştırmaya katılan 252 öğreticinin büyük çoğunluğu ön lisans ve lisans mezunu olduğu,

$\checkmark$ Araştırmaya katılan öğreticilerin çoğunluğu 4-6 yaş grubu öğrenciler ile çalışma deneyimleri en fazla 3 yıl olduğu,

$\checkmark$ Araştırmaya katılan öğreticilerin büyük kısmı daha önce müzikle uğraşmadığı,

$\checkmark$ Araştırmaya katılan öğreticilerin büyük çoğunluğu herhangi bir çalg1 çalmadığını, çalanların ise çoğunlukla bir çalgı çaldığı,

$\checkmark$ Çalg1 çaldığını belirten öğreticilerin genellikle ney, bendir, gibi Türk din mûsikîsinde kullanılan çalgılarla uğraştıkları,

$\checkmark$ 4-6 yaş Kur'an Kurslarındaki öğreticilerin okul öncesi dönemde müzik eğitimini gerekli gördükleri,

$\checkmark$ 4-6 yaş Kur'an Kurslarındaki öğreticilerin okul öncesi dönemde müzik eğitiminin çocukların psiko-motor ve bedensel gelişimine katkı sağlandığını düşündükleri,

$\checkmark \quad$ 4-6 yaş Kur'an Kurslarındaki öğreticilerin okul öncesi dönemde dini eğitimin müzik ile verilmesinin faydalı olduğunu düşündükleri,

$\checkmark \quad 4-6$ yaş Kur'an Kurslarındaki öğreticilerin okul öncesi dönemde müzikle dini eğitim verilmesi ile ilgili yeterli kaynağın olmadığını düşündükleri,

$\checkmark \quad$ 4-6 yaş Kur'an Kurslarındaki öğreticilerin okul öncesi dönemde müzik eğitimi çocuğun bilişsel gelişimine katkı sağladığını düşündükleri,

$\checkmark$ 4-6 yaş Kur'an Kurslarındaki öğreticilerin okul öncesi dönemde müzik eğitimi çocuğun dil gelişimine katkı sağladığını düşündükleri,

$\checkmark \quad$ 4-6 yaş Kur'an Kurslarındaki öğreticilerin okul öncesi dönemde müzik eğitimi çocuğun duygusal ve sosyal gelişimine katkı sağladığını düşündükleri,

$\checkmark \quad$ 4-6 yaş Kur' an Kurslarındaki öğreticilerin okul öncesi dönemde müzik eğitimi ile ilgili yeterli bilgiye sahip olmadıkları,

$\checkmark \quad$ 4-6 yaş Kur'an Kurslarındaki öğreticilerin okul öncesi dönemde müzik eğitimi ile ilgili eğitim almak istedikleri,

$\checkmark$ 4-6 yaş Kur'an Kurslarındaki öğreticilerin okul öncesi dönemde dini eğitim verirken müzikten istifade ettiği,

$\checkmark$ 4-6 yaş Kur'an Kurslarındaki öğreticilerin okul öncesi dönemde müzik eğitimi ile ilgili yeterli kaynağın mevcut olmadığını düşündükleri sonucuna varılmıştır.

Okul öncesi dönem dinî eğitimde müziğin kullanılmasının çocuklar üzerindeki etkilerinin belirlenmesi, müzikle verilecek dinî eğitim konularının tespit edilmesi, bu eğitimde kullanılacak eğitici ve öğretici materyal, metot ve kaynakların belirlenmesi ve yenilerinin oluşturulması için çalışmalar yapılmasına ihtiyaç vardır. Ayrıca planlamalar yapılarak okul öncesi dönemde dinî eğitim veren öğreticilere müzik eğitimi verilmesi en az bu çalışmalar kadar önemli olacaktır. 


\section{Kaynakça}

Başer, Fatma. "Müziğin Okul Öncesi Dönemde Çocuk Gelişimine Katkısı". Sakarya $\begin{array}{lllll}\text { Üniversitesi Eğitim } & \text { Fakültesi } & \text { Dergisi } & 8 & \text { (2004). }\end{array}$ http://dergipark.org.tr/tr/pub/sakaefd/issue/11229/134063

Erbaş, Ali. Diyanet İşleri Başkanlığı 2019 Yılı Faaliyet Raporu. Faaliyet Raporu. Ankara: Diyanet İşleri Başkanlığı, 28 Şubat 2020. Diyanet İşleri Başkanlığı. https:/ / stratejigelistirme.diyanet.gov.tr/Documents/2019\%20Y\%C4\%B11\%C4\%B1 $\%$ 20Faaliyet\%20Raporu.pdf

Erdal, Gülşen G. “Gelişim ve Öğrenme Kuramcılarına Göre Müzik Öğretim Yöntemlerinin Okul Öncesi Eğitimdeki Yeri". International Journal of New Trends in Arts, Sports $\mathcal{E}$ Science Education 1/4 (2012), 6.

Fidan, N. Okulda Öğrenme ve Öğretme. Gül Yayınevi, 1986. https:/ / books.google.com.tr/books?id=HQdPGwAACAAJ

Genç, Muhammet Fatih. “Diyanet İşleri Başkanlığı'na Bağlı 4-6 Yaş Grubu Kuran Kurslarında Din Eğitimi”. İhya Uluslararası İslam Araştırmaları Dergisi 5/2 (2019), 16.

Gün, Elmas vd. "Müzik Eğitiminin Bilişsel Gelişime Etkisi". The Journal of Academic Social Science Studies 9/Number: $50 \quad$ (01 Ocak 2016), 117-117. https://doi.org/10.9761/JASSS3555

Kabataş, Mustafa. "Çocuğun Motor, Algısal, Sosyal, Duygusal, Bilişsel ve Dil Gelişimi Dönemlerinde Müziğin Önemi". The Journal of International Educational Sciences 4/11 (01 Ocak 2017), 192-202. https:/ / doi.org/10.16991/INESJOURNAL.1406

Kol, Suat. "Erken Çocuklukta Bilişsel Gelişim ve Dil Gelişimi". Sakarya Üniversitesi Eğitim Fakültesi Dergisi, 1-21.

Okumuş, Melis. “Okul Öncesi Dönem 4- 6 Yaş Grubu Çocukların Müziksel Yaşantılarına Popüler Müziklerin Etkisi". Samsun: Ondokuzmayıs Üniversitesi Sosyal Bilimler Enstitüsü, 2008. https://tez.yok.gov.tr/UlusalTezMerkezi/TezGoster?key=Z0vbSUgrhM9fXoGkRe6Q-0S5W_87aUhqBOB4YBjVTFPeSbRajfLEs-WsawDLOSp

Ömeroğlu, E. vd. Müziğin Okul Öncesi Ĕ̆itimde Kullanılması. Kök Yayıncılık, 2003. https:/ / books.google.com.tr/books?id=wbNbtwAACAAJ

Öztürk, Ayten. Okul Öncesi Eğitimde Müzik. İstanbul: Morpa Kültür Yayınları, 2011.

Soysal, Fikri. "Erken Çocukluk Dönemi Müzik Eğitimi". The Journal of Academic Social Science Studies Volume 5 Issue 3/5 (2012), 205-221. https://doi.org/10.9761/jasss_81

Şen, Yavuz. “Okulöncesi Dönemde, Çocuğun Gelişiminde Müziğin Önemi”. Atatürk Üniversitesi Sosyal Bilimler Enstitüsü Dergisi 7/1 (18 Şubat 2010), 337-343.

Tanaltay, Suna. Çocuklar Ağlamasın. İstanbul: Tekin Yayınevi, 1997. 
Kopar, Sadettin V.-Arpa, Serbülend. 4-6 Yaş Kur’an Kursu Öğreticilerinin Okul Öncesi...

Tosun, Cemal - Çapcioğlu, Fatma. "Evaluation of Quran courses curriculum (4-6 age group ) in the context of religious development theories". Pegem Eğitim ve Öğretim Dergisi 5/5 (01 Aralik 2015), 705-720. https:// doi.org/10.14527/pegegog.2015.038

Türk, Esra. "Çocukluk Döneminde Duygusal Gelişim ve Din Eğitimi". Marife Dini Araştırmalar Dergisi 14/3 (01 Ocak 2014), 143-158.

Yağc1, Samet. “Öğreticilere göre Diyanet İşleri Başkanlığı 4-6 yaş grubu Kur'an Kursları: (İzmir İli Örneği)". İzmir Katip Çelebi Üniversitesi, 2018. http:/ / acikerisim.ikc.edu.tr:8080/xmlui/handle/11469/396

Yıldız, Gökay. İlköğretimde Müzik Öğretimi. Ankara: Anı Yayıncılık, 2002.

Yıldız, Gökay - Nacakcı, Zeki. “Okul Öncesi Dönem Çocuklarının Müziksel Gelişim Özellikleri: Bir Literatür Derlemesi". Mehmet Akif Ersoy Üniversitesi Sosyal Bilimler Enstitüsü Dergisi 8/16 (23 Eylül 2016), 38-45. https:/ / doi.org/10.20875/sb.93592 